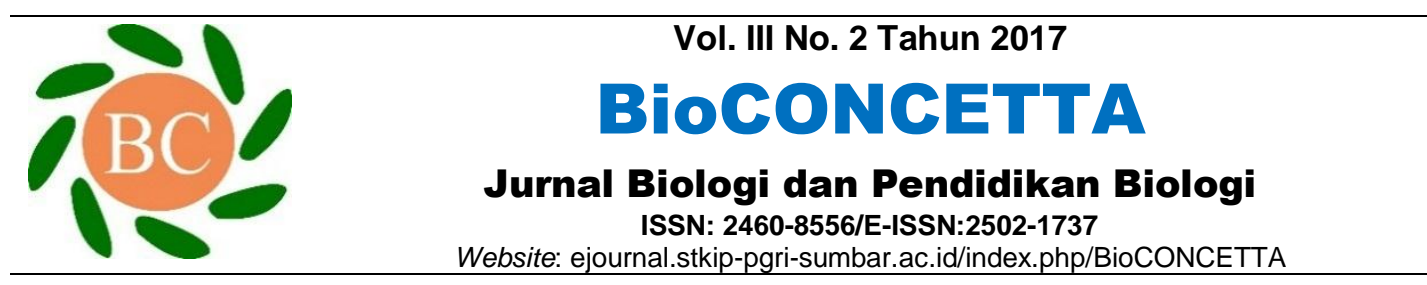

\title{
Hasil Penilaian Afektif Siswa Kelas VIII SMP dengan Menggunakan Model Pembelajaran Inkuiri Terbimbing
}

Zikra*, Mulyati, dan Endra Gusmita

Program Studi Pendidikan Biologi STKIP PGRI Sumatera Barat

Jl. Gunung Pangilun, Kota Padang, Provinsi Sumatera Barat (25137), Indonesia

E-mail: zikra.ikha@gmail.com

\section{Info Artikel}

Sejarah Artikel

Diterima:

6 Oktober 2017

Disetujui:

22 November 2017

Dipublikasikan:

4 Desember 2017

Kata Kunci:

efektivitas, inkuiri

terbimbing, biologi

Keywords:

affective, guided

inquiry, biology

\begin{abstract}
Abstrak
Penelitian bertujuan untuk mengetahui penerapan model pembelajaran inkuiri terbimbing terhadap hasil belajar biologi siswa tahun kedua SMP pada ranah afektif. Penelitian dilaksanakan pada semester ganjil tahun ajaran 2017/2018. Jenis penelitian adalah eksperimen dengan menggunakan rancangan penelitian randomized control group postest only design. Penelitian menggunakan dua kelas sampel yaitu kelas eksperimen dengan perlakuan penerapan model pembelajaran inkuiri terbimbing dan kelas kontrol menggunakan metode belajar konvensional. Instrumen penelitian yang digunakan adalah lembar observasi penilaian sikap. Indikator yang dinilai yaitu tanggung jawab dan percaya diri. Hasil penelitian yang diperoleh yaitu nilai afektif ratarata kelas eksperimen adalah 82,50 (Baik) dan nilai-rata-rata kelas kontrol adalah 73,85 (Baik). Hipotesis diterima karena $t_{\text {hitung=3,26 }}>$ $\mathrm{t}_{\text {tabel}=1,672}$, dan terdapat perbedaan hasil belajar siswa pada kedua kelas sampel secara signifikan, jadi penerapan model pembelajaran inkuiri terbimbing dapat meningkatkan hasil belajar biologi siswa tahun kedua SMP pada ranah afektif.
\end{abstract}

\begin{abstract}
The objective of this research is to know the application of guided inquiry learning model to the biology learning result of the students of second years of yunior high school in the affective domain. The study was conducted in the odd semester of the academic year 2017/2018. The research is an experimental research using randomized control group postest only design research design. The study used two sample classes: the experimental class with given the application of Inquiry guided learning model and the control class using conventional learning method. The research instrument used is observation sheet of attitude evaluation. Indicators assessed are responsibility and confidence. The result showed that the average affective value of the experimental class is 82,50 (Good predicate) and the control class average is 73,85 (Good predicate). Working hypothesis accepted because $t_{\text {count }}=3.26>t_{\text {table }}=1.672$, and there are differences in student learning outcomes in both classes of samples significantly. That is means the implementation of Inquiry Learning model can improve the learning outcomes of biology of grade VIII SMP students affective.
\end{abstract}




\section{PENDAHULUAN}

Belajar dapat dipandang sebagai proses yang diarahkan kepada pencapaian tujuan dan proses berbuat melalui berbagai pengalaman yang diciptakan guru (Rusman, 2017) Pembelajaran berupaya mengubah masukan berupa siswa yang belum terdidik, menjadi siswa yang terdidik, siswa yang belum memiliki pengetahuan tentang sesuatu, menjadi siswa yang memiliki pengetahuan. Demikian pula dengan siswa yang memiliki sikap, kebiasaan atau tingkah laku yang belum mencerminkan eksistensi dirinya sebagai pribadi baik atau positif, menjadi siswa yang memiliki sikap, kebiasaan dan tingkah laku yang baik.

Menurut Kunandar (2013), objek sikap yang perlu dinilai dalam proses pembelajaran salah satunya adalah sikap terhadap proses pembelajaran. Dimana peserta didik perlu memiliki sikap positif terhadap pembelajaran yang berlangsung mencakup suasana pembelajaran strategi, metodologi dan tehnik pembelajaran yang digunakan

Berdasarkan wawancara dengan guru biologi kelas VIII yang mengajar di SMPN 3 Lembah Gumanti Kabupaten Solok pada bulan juni 2017 ditemukan pembelajaran masih terpusat pada guru, metode ceramah dengan menggunakan media papan tulis yang digunakan belum dapat menarik minat serta motivasi belajar siswa.

Siswa tidak dilibatkan secara lansung dalam proses pembelajaran sehingga membuat siswa tidak aktif dan rendahnya rasa percaya diri siswa yang terlihat dari masih banyak siswa yang tidak mengeluarkan pendapat, mengajukan pertanyaan ataupun menjawab pertanyaan, hal ini membuat rendahnya rasa ingin tahu siswa untuk mengkaji materi pelajaran lebih dalam dan rendahnya rasa tanggung jawab siswa dalam mengerjakan tugas yang diberikan guru, banyak siswa yang tidak mengumpulkan tugas sesuai dengan waktu yang ditentukan guru dan mengerjakan tugas tidak sesuai dengan tujuan pembelajaran. Salah satu mateti pelajaran yang nilai siswa tidak mencapai batas kriteria ketuntasan minimal (KKM) adalah materi zat adiktif dan psikotropika, model pembelajaran inkuiri belum pernah diterapkan oleh guru untuk pembelajaran IPA.

Untuk mengatasi permasalahan tersebut maka guru dituntut untuk lebih 
kreatif dalam menggunakan berbagai model pembelajaran yang tepat sehingga dapat meningkatkan hasil belajar siswa dan pembelajaran akan memberikan makna tersendiri bagi siswa. Salah satu model yang dapat digunakan adalah model pembelajaran inkuiri terbimbing, dimana pada model ini akan menumbuhkan rasa ingin tahu siswa dengan bimbingan guru. Menurut Sanjaya (2008) pembelajaran inkuiri terbimbing yaitu suatu pembelajaran inkuiri yang dalam pelaksanaannya guru menyediakan petunjuk cukup luas kepada siswa. Sebagai perencanaannya dibuat oleh guru, siswa tidak merumuskan problem atau masalah.

Dalam pembelajaran inkuiri terbimbing guru tidak melepas begitu saja kegiatan kegiatan yang dilakukan oleh siswa. Guru harus memberikan pengarahan dan bimbingan kepada siswa dalam melakukan kegiatankegiatan sehingga siswa yang berfikir lambat atau siswa yang mempunyai intelegensi rendah tetap mampu mengikuti kegiatan-kegiatan yang dilaksanakan. Menurut Wulanningsih dan Riezky (2012) model pembelajaran inkuiri terbimbing merupakan pembelajaran yang terpusat pada siswa.
Model pembelajaran inkuiri terbimbing ini guru yang berperan penting dalam membimbing siswa saat menemukan inti dari materi ajar itu sendiri dengan memberikan beberapa pertanyaan. Dari pertanyaan itu siswa dituntut untuk membuat hipotesis awal terhadap pertanyaan guru, kemudian siswa mengumpulkan data dengan membaca berbagai sumber dan menjawab pertanyaan guru sesuai dengan data yang didapatkan.

Menurut Ambarsari dan Maidi (2013) pembelajaran inkuiri terbimbing merupakan suatu cara yang efektif untuk membuat variasi suasana pola pembelajaran kelas. Pembelajaran inkuiri terbimbing merupakan pembelajaran kelompok dimana siswa diberi kesempatan untuk berfikir mandiri dan saling membantu teman yang lain dan pembelajaran ini membimbing siswa untuk memiliki tanggung jawab individu dan tanggung jawab dalam kelompok.

Penelitian ini bertujuan untuk mengetahui nilai afektif siswa SMP N 3 Lembah Gumanti Kabupaten Solok dengan menggunakan model pembelajaran Inkuiri Terbimbing. Manfaat penelitian adalah sebagai bahan pertimbangan bagi guru IPA 
pada umumnya untuk menggunakan model inkuiri terbimbing pada proses pembelajaran sehingga dapat meningkatkan nilai afektif siswa.

\section{BAHAN DAN METODE}

Penelitian ini telah dilaksanakan pada semester ganjil tahun ajaran 2017/2018 dan bertempat di SMP N 3 Lembah Gumanti Kabupaten Solok, yang dilaksanakan pada bulan November. Jenis penelitian ini adalah Penelitian eksperimen. Penelitian ini menggunakan dua kelas sampel yaitu kelas eksperimen dan kelas kontrol. Rancangan penelitian yang digunakan adalah Randomized Control Group Postest Only Design. Pada kelas eksperimen diberikan perlakuan penerapan model pembelajaran Inkuiri Terbimbing sedangkan pada kelas kontrol menggunakan metode ceramah dan tanya jawab. Populasi dalam penelitian ini adalah seluruh siswa kelas VIII SMP N 3 Lembah Gumanti Kabupaten Solok, tahun pelajaran 2017/2018. Teknik pengambilan sampel dalam penelitian ini adalah teknik purposive sampling, dengan kriteria nilai yang sama atau mendekati sama. Prosedur penelitiannya ada tiga, tahap persiapan, tahap pelaksanaan dan tahap penyelesaian, instrumen penelitian yang digunakan adalah lembar observasi pada ranah afektif. Teknik analisis data menggunakan uji normalitas, uji homogenitas dan uji hipotesisi menggunakan uji t karena data berdistribusi normal dan homogen.

\section{HASIL DAN PEMBAHASAN}

Berdasarkan hasil penelitian dengan penerapan model pembelajaran inkuiri terbimbing terhadap hasil belajar biologi siswa kelas VIII SMP N 3 Lembah Gumanti Kabupaten Solok didapat hasi yang dapat dilihat pada Tabel 1.

Tabel 1. Hasil belajar siswa pada ranah afektif

\begin{tabular}{|c|c|c|c|}
\hline \multirow{2}{*}{ No. } & \multirow{2}{*}{ Parameter } & \multicolumn{2}{|c|}{ Afektif } \\
\hline & & Eksperimen & Kontrol \\
\hline 1 & Nilai Rata-Rata & 82,50 & 73,85 \\
\hline 2 & Predikat & Baik (B) & Baik (B) \\
\hline 3 & Uji Hipotesis & \multicolumn{2}{|c|}{$\begin{aligned} \mathrm{t}_{\text {tabel }}= & 1,672\left(\mathrm{t}_{\text {hitung }}>\mathrm{t}_{\text {tabel }}\right) \\
& \mathrm{t}_{\text {hitung }}=3,26\end{aligned}$} \\
\hline 4 & Keterangan & Hip & $\mathrm{ma}$ \\
\hline
\end{tabular}


Berdasarkan Tabel 1 terlihat bahwa bahwa nilai afektif rata-rata kelas eksperimen adalah 82,50 dengan predikat baik (B) dan nilai-rata-rata kelas kontrol adalah 73,85 dengan predikat baik (B). Hipotesis kerja diterima karena $t_{\text {hitung }=3,26}>t_{\text {tabel }=1,672,}$ dan terdapat perbedaan hasil belajar siswa pada kedua kelas sampel secara signifikan. Berarti penerapan model pembelajaran Inkuiri Terbimbing dapat meningkatkan hasil belajar biologi siswa kelas VIII SMP N 3 Lembah Gumanti Kabupaten Solok pada ranah afektif.

Penilaian afektif dilakukan selama proses pembelajaran berlangsung. indikator yang dinilai yaitu tanggung jawab dan percaya diri. Rata-rata nilai perindikator kelas sampel pada ranah Afektif dapat dilihat pada Gambar 1.

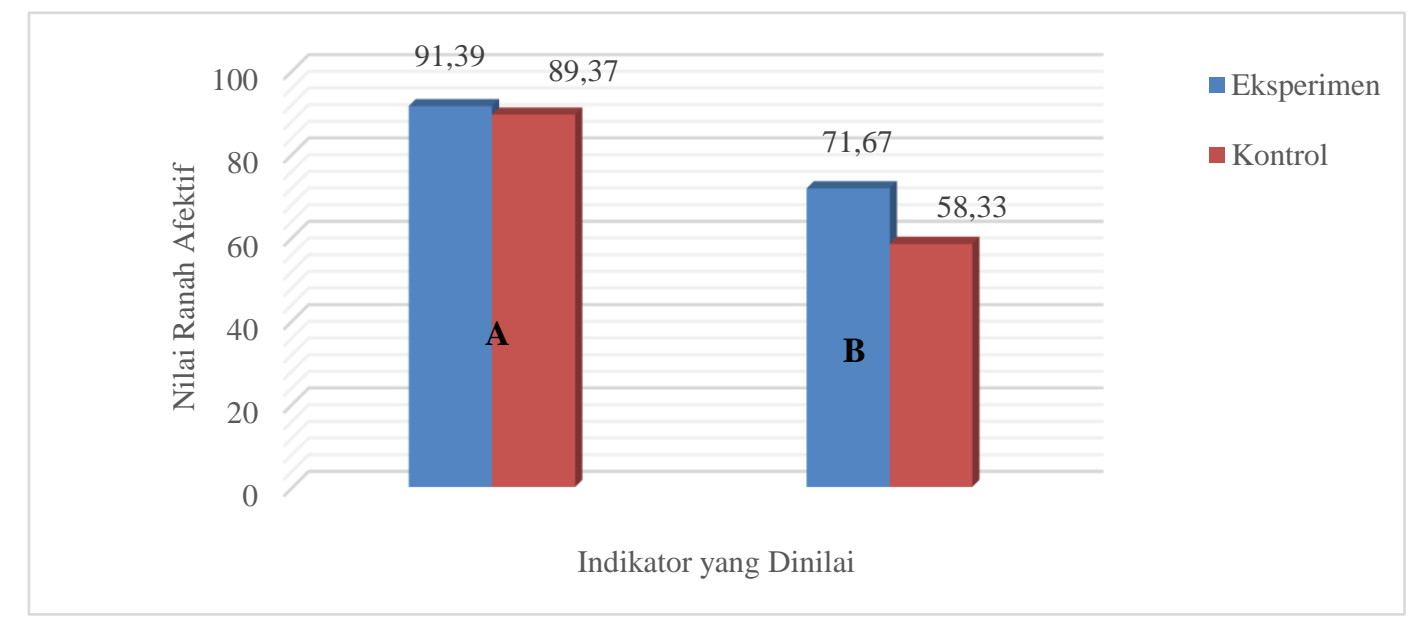

Gambar 1. Rata-rata nilai afektif perindikator siswa kelas pada sampel; batang A; Tanggung Jawab, batang $\mathrm{B}=$ Percaya Diri

Berdasarkan Gambar 1 penilaian sikap kelas sampel pada indikator bertanggung jawab mendapatkan predikat sangat baik (A) untuk kelas eksperimen dan kelas kontrol, sedangkan pada indikator percaya diri kelas eksperimen mendapat predikat baik (B) dan kelas kontrol mendapat predikat cukup (C).
Presentase ketuntasan siswa pada kelas sampel dengan batas Kriteria Ketuntasan Minimal (KKM) 76 untuk ranah afektif, pada kelas eksperimen siswa yang berada di atas KKM sebanyak 21 orang $(70 \%)$ sedangkan yang berada di bawah KKM sebanyak 9 orang $(30 \%)$ dan pada kelas kontrol siswa yang mencapai batas KKM 
adalah 11 orang (38\%) dan yang dibawah KKM sebanyak 18 orang $(63 \%)$

Penilaian ranah afektif dengan menggunakan lembaran observasi yang telah diisi oleh observer selama 3 kali pertemuan. Tingginya nilai kelas eksperimen terjadi karena siswa mengerjakan tugas yang diberikan guru secara berkelompok dengan bertanggung jawab hal ini saat siswa mengerjakan tugas yang diberikan guru melalui lembar diskusi siswa tepat waktu sesuai dengan instruksi guru. Menurut Sanjaya (2008: 246-247) keberhasilan kelompok tergantung pada setiap anggotanya, maka setiap anggota kelompok harus memiliki tanggung jawab sesuai dengan tugasnya.

Pada saat diskusi dan presentasi kelompok didepan kelas siswa pun dengan percaya diri mengajukan pendapat dan memberikan pertanyaan serta tanggapan dari presentasi yang telah dilakukan siswa lain. Akibatnya terjadi interaksi antar siswa dengan lingkungannya. Menurut (Maqassary, 2014) Percaya diri seseorang dapat tumbuh apabila individu tersebut mampu melakukan komunikasi dan interaksi dengan lingkungan sekitarnya secara baik, kemampuan melakukan semua itu dapat menumbuhkan rasa percaya diri pada diri seseorang. Ditambahkan oleh Gulo (2011:85) bahwa pembelajarn dengan model Inkuiri Terbimbing dapat mengembangkan sikap percaya diri pada diri siswa.

Hasil penilaian Afektif siswa pada kelas kontrol dengan metode ceramah dan tanya jawab masih rendah dari kelas eksperimen yang menggunakan model pembelajaran Inkuiri Terbimbing, karena pada kelas kontrol siswa mengerjakan tugas dan bertanggung jawab terhadap tugas sendiri, siswa yang sudah terbiasa mencontoh tugas temannya apabila diminta untuk mengerjakan tugasnya secara individu akan kurang bertanggung jawab, dan tidak menyelesaikan tugasnya tepat waktu sesuai dengan waktu yang telah di tentukan guru pada saat proses pembelajaran. Menurut Slameto (2003: 66) menciptakan relasi yang baik antar siswa sangat diperlukan agar dapat memberikan pengaruh yang positif terhadap hasil belajar siswa.

Faktor lain yang menyebabkan siswa kelas kontrol mendapatkan nilai dengan predikat $\mathrm{C}$ yaitu siswa kurang 
percaya diri dan enggan untuk mengeluarkan pendapat pada saat ditanya oleh guru maupun mengajukan pertanyaan saat diberikan kesempatan oleh guru untuk bertanya. Menurut Majid (2013:199) metode ceramah tidak dapat memberikan kesempatan siswa untuk berdiskusi memecahkan masalah sehingga proses menyerap pengetahuannya kurang tajam.

\section{SIMPULAN}

Berdasarkan hasil penelitian yang telah dilakukan, dapat disimpulkan bahwa model pembelajaran inkuiri terbimbing dapat meningkatkan hasil belajar biologi pada ranah afektif pada siswa tahun kedua SMPN tahun ajaran 2017/2018.

\section{DAFTAR PUSTAKA}

Ambarsari, S. dan Maridi. 2013. Penerapan Model Pembelajaran Inkuiri Terbimbing Terhadap Keterampilan Proses Sains Dasar Pada Pelajaran Biologi Siswa Kelas VIII SMP Negeri 7 Surakarta. Jurnal penelitian pendidikan eksperimen, 5(1): 81-.95.

Gulo, W. 2002. Strategi belajar mengajar. 2011. Jakarta: PT Grasindo
Karenta, R.U. 2013. Penerapan Model Pembelajaran Inkuiri Terbimbing (Guided Inquiry) Untuk Meningkatkan Prestasi Belajar Siswa Pada Pokok Bahasan Hidrolisis Garam di Kelas IX IPA SMA Negeri 5 Pekanbaru

Kurniati, M. dan Sulistyo. 2016. Penerapan Model Pembelajaran Inkuiri Terbimbing Dilengkapi LKS Untuk Meningkatkan Keterampilan Proses Sains Dan Presetasi Belajar Pada Materi Pokok Hukum Dasar Kimia Siswa Kelas X MIA 4 SMA N 1 Karanganyar Tahun Pelajaran 2014/2015. Jurnal Pendidikan Kimia (JPK). 5 (1): 88-95.

Majid, A. 2013. Pembelajaran Tematik Terpadu. Bandung: Remaja Rosdakarya Offset.

Pramono, S. 2014. Panduan Evaluasi Kegiatan Belajar Mengajar Teknik Membuat Evaluasi Berbagai Model Soal. Jogjakarta: DIVA Press

Rusman. 2017. Belajar dan Pembelajaran. Jakarta: kencana

Sanjaya, W. 2008. Media Komunikasi Pembelajaran. Jakarta: Prenada Media Group.

Slameto. 2003. Belajar dan FaktorFaktor yang Mempengaruhinya. Jakarta: PT. Raja Grafindo Persada.

Kunandar. 2013. Penilaian Autentik. Jakarta. Raja Grafindo Persada 
Wulanningsih, B. dan Riezky. 2012. Pengaruh Model Pembelajaran Inkuiri Terbimbing Terhadap Keterampilan Proses Sains
Ditinjau Dari Kemampuan Akademik Siswa SMA Negeri 5 Surakarta. Jurnal penelitian biologi. 2 (3): 33-44. 